\title{
EEN VERLOREN SCHAAP NOG NIET GEHEEL TERECHT.
}

DOOR

\author{
J. L. VAN GENNEP.
}

In de Bijdragen tot de Taal- Land- en Volkenkunde van Nederlandsch-Indië, zesde volgreeks, achtste deel, (1901), beschrijft de heer C. M. Pleyte op bladzijde $634-637$ een van tufsteen gehouwen Garuda-kop, aanwezig in 's Rijks Museum van Oudheden te Leiden, en vermeent hij dat deze daemonenkop afkomstig zou zijn van den Tjandi-Djaboeng nabij Padjarakan, afdeeling Kraksaän.

Deze onderstelling is echter onjuist, zooals mij bij het onderzoek, dat ik onlangs persoonlijk aan dien Tjandi instelde, gebleken is in verband met drie dergelijke daemouenkoppen, welke in den Noordwestelijken hoek van het erf der Assistent-Residentswoning te Kraksaän tegen een kunstmatig gevormd heuveltje onder een waringinboom opgesteld zijn.

Volgens getuigenis van inlanders uit de dessa Tjandi-Djaboeng, o. a. van den bewaker van den tempel, zou de Banaspati welke boven den ingang van den Tjandi-Djaboeng ontbreekt - terwijl zij boven de drie ter weêrs- en achterzijden geplaatste blinde vensters wel voorkomen - vele tientallen jaren geleden getroffen zijn door den bliksem die tevens den top van den Tjandi trof, en zou dit sluitstuk dientengevolge neergestort en in stukken gevallen zijn, welke stukken weggeruimd zijn.

Niets was hun bekend van het feit, dat deze kop weggehaald en aan Europeanen van een zeilschip zou zijn afgegeven. Zij beweerden volgens de verhalen hunner ouders zeker te weten dat de kop in stukken is neergestort.

Zulks is trouwens wel aan te nemen, indien men nagaat dat de geheele tempel en ook de daemonenkop van rooden baksteen is gebouwd; ongetwijfeld moet die kop bij het nedervallen van een hoogte van 11 meter in stukken versplinterd zijn. De drie nog 
aanwezig zijnde Banaspatis zijn ook allen van baksteen, niet van tufsteen, en zijn zeer fraai.

$\mathrm{Bij}$ een meting van het vak in den wand boven den ingang waarin de kop gezeten moet hebben, bevond ik voor de breedte $1.25 \mathrm{M}$. en de hoogte $1.01 \mathrm{M}$.

Wegens het verschillend gehalte van het bouwmateriaal is het reeds duidelijk dat de Garuda-kop (Banaspati), door den heer Pleyte beschreven, niet afkomstig kan zijn van den Tjandi-Djaboeng. Ook het feit dat deze kop naar verluidt afkomstig was uit de dessa Padjarakan bewijst dit eenigszins, dewijl deze dessa 2 paal bewesten de hoofdplaats Kraksaän, en de Tjandi-Djaboeng 5 paal beoosten die hoofdplaats gelegen is. De vroeger bestaande, thans afgebroken suikerfabriek Djaboeng nabij die Tjandi behoorde tot de oudste fabrieken en heeft nog aan een chinees toebehoord die het riet middels een molen, door karbouwen voortbewogen, vermaalde; zij was ouder dan de fabriek Padjarakan en kwamen in vroegere jaren vermoedelijk schepen er even goed de suiker halen, welke toen op de reede voor Djaboeng moeten gelegen hebben, als anderen voor Padjarakan ten anker gingen.

Was dus de kop van Tjandi-Djaboeng afkomstig, dan zou zulks ook wel door den kapitein van het schip dat hem heeft medegebracht vermeld zijn geweest, instede van te berichten dat hij uit de dessa Padjarakan kwam.

Deze dessa heeft vermoedelijk ook een oudheid gehad, althans niet ver daar bezuiden, in de dessa Ketompen-wètan, gehucht Kentroong, moet een tempel of iets dergelijks volgens de overlevering gestaan hebben. Zekerheid heb ik daaromtrent niet kunnen krijgen, maar thans zijn nog enkele brokstukken van ruw gehouwen beelden, zooals een ruw steenen beeld, het bovenlijf van een tempelwachter, een kop, een vuist, een voet en een ruw afgewerkte kop van een slang, aldaar op een door boomen omgeven pleintje midden in de sawah aanwezig.

Voorheen waren op het erf van de vroegere kawedanan van Padjarakan (thans is het district opgeheven tengevolge van de bestuurs-reorganisatie) nog twee fraaie voetstukken voorhanden, beschreven in Verbeeks "Oudheden van Java", onder No 635 op bladzijde 311. Deze thans zich niet meer daar bevindende voetstukken moeten volgens de bewering van de dessahoofden ook afkomstig zijn uit gemeld gehucht Kentroong, dessa Ketompen-wètan.

De drie op het erf van de Assistent-Residentswoning tc Kraksaän 
zich bevindende Banaspatis zijn vermoedelijk ook uit die dessa afkomstig en zijn mede van tufsteen vervaardigd.

Naar de beschrijving, die de heer Pleyte van zijn daemonenkop geeft, heeft deze kop veel overeenkomst met twee dier koppen, die elk ook voorzien zijn van een trapvormig uitgehakten achterkant.

Van de eene kop bedragen de hoogte, breedte en diepte 0.91 M., 0.84 M. en 0.90 M. terwijl de dikten over den trapvormig uitgekapten achterkant, van boven naar beneden gemeten, $0.27 \mathrm{M}$., 0.15 M., 0.14 M. en 0.27 M., de breedten der treden in dezelfde volgorde $0.21 \mathrm{M}$., $0.16 \mathrm{M}$. en $0.17 \mathrm{M}$. bedragen en het bovenvlak $0.40 \mathrm{M}$. breed is.

De andere kop heeft de volgende afmetingen, als: $0.90,0.84$ en $0.95 \mathrm{M}$.; de trapvormig uitgekapte achterkant is dik $0.24,0.14$, 0.13 en 0.27 M. en breed $0.21,0.16$ en $0.16 \mathrm{M}$., het bovenvlak echter $0.40 \mathrm{M}$.

De derde kop is veel kleiner: $0.85 \mathrm{M}$. hoog, $0.59 \mathrm{M}$. breed en 0.4l M. diep. De achterzịjde heeft slechts ééne trapvormig uitgesneden trede.

Hoewel de herkomst dezer drie Banaspatis mij niet bekend is, vermeen ik toch dat zij, evenals de door den heer P. bedoelde, van de dessa Ketompen-wètan bezuiden. Padjarakan afkomstig zijn, maar in geen geval van Tjandi-Djaboeng.

De koppen zijn trouwens veel ruwer afgewerkt dan de Banaspatis op Tjandi-Djaboeng.

Kraksaün, 12 October 1901. 